\section{0-241 エストラジオールはサブスタンスPの発現} を通じてラット春蹃の知觉過敏状態に影䈉 を与える。一特に慢性的膀胖刺激の影響について

\begin{abstract}
山形大学 医学部 泌尿器科 1 )

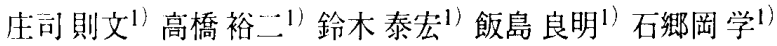
笹川五十次 ${ }^{1)}$ 久保田 洋子 ${ }^{1)}$ 中田瑛浩1)

【日的】閉経後の女性の無菌性膀胱刺激症状を中枢性の知覚過敏 反志と考え、雌Splague-Dawly (SD) ラットを用いneuroransmittorの一 つである substance P（SP）の求心性上行路での発現の仕方を下部

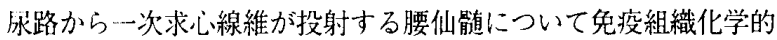
に検討を行った。【对象と方法】雌SDラット計54匹に対して Leuprolide(LH-RH)皮下注、エストラジオール(E2)皮下注を加え、無 菌的膀脱炎を出現させるためcyclophosphamide(CPA)を腹腔内投与 し、4週間後にavidin-viotin法を用い腰仙䯣部のSP染色の局在とその 部位の染色性の強さを半定量的に計測した。【結論】慢性的膀胱 刺激によって䄃䯣内のSPが放出されるが、LH-RH投与によってSP の合成が増加しより多くのSPが放出されcentral hypersensitivityを形 成するものと考えられた。またE2投与によってSPの合成は抑制さ れSPの放出が減少するものと推察された。このためE2投与は central hypersensitivity孝防し得るものと考えられた。
\end{abstract}

substance $P$ postmenopausal women estradiol

\section{0-242 間質性竍胱炎の診断に関する検討}

\begin{abstract}
原三信病院 泌尿器科 ${ }^{1)}$

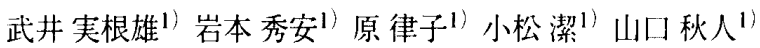
原三信 ${ }^{1)}$

【目的】間質性膀胱炎は稀な疾患と認識されているが、奏際には 類似の症状を呈する症例は少なくない。その理由として、診断基 準方暧昧で的確な治療方法も確立されていないため、診断の努力 がなされないままに慢性膀胱炎などの病名で片付けられている叮 能性があると考えられる。今回われわれは本疾患に対する適切な 診断方法は何かを確認する目的で、過去9年間に当院で間質性膀 胱炎と診断された症例を検討したので報告する。【対象と方法】 1989年から1998年までの10年間に間質性膀胱炎と診断された症例 は44例あり、男性6例、女性38例、平均年齢59歳であったここれら の症例に対し診断までの症状、経過抢よび検査結果を検討した。 【結果】症状は頻尿と膀胱部痛がほとんどであり、診断までに平 均5年を要していた。麻酔下の水压負荷膀胱鏡が施行された 中、3例にHunner潰瘍、8例にcracksを認め、残りの全例に点状出血 (glomerulation)を認めた。膀胱粘膜の組織所見では特徽的なもの はなかった。結論】間質性膀胱炎の診断根拠として麻酔下の水 圧負荷膀胱鏡所見の重要性が確認された。間質性膀胱炎に関する 研究が急速に進展しつつある現在、類似の疾患も含めて疑わしい 症例には、麻酔下の水圧負荷膀胱鏡を積極的に施行する意義があ ると考える。
\end{abstract}

\section{間質性膀胱炎 診断 水圧負荷竍胱鏡}

\section{O-244 自然消失を証めた小児膀胱尿管逆流症の検 討}

\begin{abstract}
東京慈恵会医科大学 医学部
県立厚木病院 ${ }^{2}$

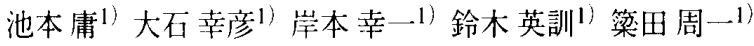
加藤 伸樹1) 田代 和也 $^{2)}$

【目的】経腹式、経膣式 2 つの膀胱胵廔閉鎖術の臨床的有用性の 比較検討。【対象㧍よび方法】膀胱缸摟に対し過去22年間に当教 室で行なわれた13[回の膀脱胵瘦閉鎖術(12症例)を retrospectiveに検討 し、特にLatzkoの方法に準じた経脆式閉鎖術の適応、術式、成績 を検証した。【結果】1977年から1999年までに慈恵医大病院、県立 厚木病院で行われた膀胱膣瘦閉鎖術は13回12例で、淕式閉鎖術(7 例)と経腹式閉鎖術(6例)であった。年齢は28から66（中央値42）歳、 瘦孔をきたした原疾患は膀胱異物 1 例で、他はすべて外科手術に よるものであった。手術までの期間は最短 1 ケ月から最長 1 年ま でであったが、経㓐式では 3 ヶ月待ってから行った例がほとんど であった。瘦孔の数は 1 例が 2 孔であったが、他は 1 孔であり、 㜢孔径は2-8 mmであったが、経㓐式では径の小さいものが多か つた。また経胵式では手術時間も短く、術後離休も早期であった。 成績は経胵式の1例で閉鎖不全がみられ、経腹式に再手術、閉鎖 したが、他は全例 1 回の手術で開鎖した。【結論】Latzkoの方法に 潐じた部分的嘋閉鎖術は本邦での報告は少ないが、適応を絞れば 低骎畩で、成績良好な術式と思われた。
\end{abstract}

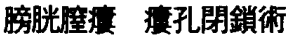

\begin{abstract}
宮崎医科大学 医学部 泌尿器科 1 )
長野正史 ${ }^{1)}$ 上村敏雄 ${ }^{1)}$ 月野浩昌 ${ }^{1)}$ 高橋尚也”竹原俊幸11 濱砂良一1）蓮井良浩1) 長田幸夫 $\left.{ }^{1}\right)$

【目的】今回我々は膀胱尿管逆流症（VUR）の治療経過中にVUR の自然消失を認めた症例につき臨床的検討を加えたので報出す る。【対象と方法】1998年12月までの間に当科にてVURと診断され た初診時年齢15歳までの症例109例中、途中脱落例を除く94例140 尿管を対象とした。【結果】原発性VUR症例で自然消失を認めた のは71例112尿管中21例 $(29.5 \%)$ 28尿管 (25\%) であった。性別 では男罗24例中5例 $(20.8 \%)$ 、女北47例中16例 $(34 \%)$ で、恝側は 両側7例 $(17 \%)$ 、左7例 $(46.6 \%)$ 、右 7 例 $(46.6 \%)$ であった。 側VUR症例では初診より1年以内に消失を認めた症例が11氺管 68.8\%であったが、両側VUR例では 5 尿管35.7\%であった。目然消 失を認めた 28 尿管中 26 尿管は 2 年以内に消失した。初診時年戟が 低い程自然消失率は高く、VUR gradeの高い例でも消失が見られた。 続発性VUR症例では23例32尿管中10例 $(43.5 \%)$ 12尿管 $(37.5 \%)$ で抗コリン郕の投与や間欠導家の施行によりVURの消失を認め た。VURの消失を認めた12氺管中11疗管はgrade I、IIのgradeの軽い ものであった。【考察】低年㱓、低grade、片側性、女昌の主然消 失率か高い傾向にあった。しかし年齢、grade、性別にかかわらず、 初診より2年経過後もVURが残存する症例では自然消失する叮能 性は低く、他の治療法の検討も必要と思われた。
\end{abstract}

膀胱尿管逆流症 自然消失 